\title{
Isolation of enzymes involved in threonine biosynthesis from sorghum seeds
}

\author{
Renato Rodrigues Ferreira ${ }^{1}$, Ariane Vendemiatti ${ }^{2}$, Lyndel Wayne Meinhardt ${ }^{1}$, Peter John Lea ${ }^{3}$ and Ricardo \\ Antunes Azevedo ${ }^{2 *}$
}

${ }^{1}$ Departamento de Genética e Evolução, Instituto de Biologia, CP 6109, Universidade Estadual de Campinas, CEP 13083-970, Campinas, SP, Brasil; '2Departamento de Genética, Escola Superior de Agricultura Luiz de Queiroz, Universidade de São Paulo, CP 83, CEP 13418900, Piracicaba, SP, Brasil; ${ }^{3}$ Department of Biological Sciences, Lancaster University, Lancaster, Lancashire, LA1 4YQ, United Kingdom; *Corresponding author: raazeved@esalq.usp.br

Received: 10/04/2004, Accepted: 19/06/2004

Cereal seeds are poor in essential amino acids, particularly lysine, tryptophan and threonine. The amino acids lysine and threonine are synthesized in the aspartate pathway. Although most of the enzymes of the aspartate pathway have been isolated and characterized in higher plant species, the metabolism of lysine and threonine is totally unknown in sorghum. We have isolated two enzymes, aspartate kinase (AK) and homoserine dehydrogenase (HSDH) from sorghum. Optimum assay conditions were established for the determination of AK and HSDH activities. The highest level of activity was observed in immature seeds. AK was shown to be inhibited by threonine and lysine indicating the existence of at least two isoenzymes, one sensitive to threonine inhibition and the other sensitive to lysine inhibition with the latter being predominant in sorghum seeds. HSDH was shown to be inhibited by threonine indicating the existence of a threonine-sensitive HSDH, however, most of the activity was not inhibited by threonine, suggesting the existence of a second predominant isoenzyme of HSDH resistant to threonine inhibition.

Key words: amino acids, aspartate kinase, homoserine dehydrogenase, lysine, threonine.

Isolamento de enzimas envolvidas na biossíntese de treonina em sementes de sorgo: As sementes dos cereais são pobres em aminoácidos essenciais, principalmente lisina, triptofano e treonina. Os aminoácidos lisina e treonina são sintetizados na via metabólica do aspartato. Apesar de a maioria das enzimas da via do aspartato ter sido isolada e caracterizada em várias espécies de plantas, o metabolismo de lisina e treonina é totalmente desconhecido em sorgo. Isolamos duas enzimas, aspartato quinase (AK) e homosserina desidrogenase (HSDH) de sorgo, estabelecendo condições ótimas de ensaio para determinação da atividade de AK e HSDH. Observaram-se as atividades mais elevadas de AK e HSDH em sementes imaturas. A atividade de AK foi inibida por treonina e lisina, indicando a existência de duas isoenzimas, uma sensível à inibição por treonina e, a outra, sensível à inibição pela lisina, predominando, esta última, nas sementes de sorgo. A atividade de HSDH foi inibida por treonina, indicando a existência de uma isoenzima sensível à treonina, a maioria da atividade, entretanto, não foi inibida por treonina, sugerindo a existência de uma segunda isoenzima de HSDH predominante resistente à inibição pela treonina.

Palavras-chave: aminoácidos, aspartato quinase, homoserina desidrogenase, lisina, treonina.

\section{INTRODUCTION}

The classic role of agricultural crops as the major food supplier to feed a growing and hungry population is still substantial, but today there is also a great demand to improve the nutritional quality of the food (Kingston-Smith and Thomas, 2003). This may help to solve problems encountered in cases where plants are the major or sole source of food, as well as plant feeds for livestock, which are consumed as human foods (Galili et al., 2002).

Non-ruminant animals (such as humans, poultry, and pigs) cannot synthesize 9 out of the 20 protein amino acids and therefore have to obtain them in their diets. Although 
ruminant animals (such as cattle and sheep) also cannot synthesize essential amino acids, they have special microbial flora in their rumen, which are able to synthesize essential amino acids and incorporate them into microbial proteins, that later become available for nutrition. However, these microbial proteins provide only $65 \%$ of the total protein required for intensive milk production. Hence, ruminant animals also suffer from limitations in essential amino acids (Leng, 1990).

Cereal grains represent the main dietary source of protein for human and livestock worldwide. Sorghum is one of the most important cereal crops, representing a major source of energy and protein for millions of people, especially in Africa and for livestock worldwide. Unfortunately, the protein quality is low due to essential amino acid imbalance resulting from the ratio between the different storage proteins (Azevedo et al., 2003, 2004). The largest group, the prolamins, contains only traces of lysine and threonine (Vernaillen et al., 1993).

Essential amino acids like lysine and threonine are particularly important in cereal crops, due to the low concentration in the seeds (Fornazier et al., 2003). These amino acids, plus methionine and isoleucine have a common precursor, aspartate (Azevedo and Lea, 2001). The aspartate metabolic pathway in plants is strongly feedback regulated at key enzyme steps (Azevedo et al., 1997). Several enzymes of the aspartate pathway have been shown to be important for the control of the fluxes of carbon and nitrogen through the pathway, leading to the synthesis of lysine and threonine (Azevedo et al., 1997). Among them, aspartate kinase (AK, EC 2.7.2.4), homoserine dehydrogenase (HSDH, EC 1.1.1.3), dihidrodipicolinate synthase (DHDPS, EC 4.1.2.52) and threonine synthase (TS, EC 4.2.99.2) have been characterised in a number of plants species, with some being shown to be present in different isoenzymic forms (Azevedo et al., 1992a; Teixeira et al., 1998; Vauterin et al., 1999).

AK catalyses the phosphorylation of aspartate to produce $\beta$-aspartyl phosphate (figure 1, Azevedo and Lea, 2001). In higher plants species, up to three isoenzymes have been observed, which can be classified into two groups; lysinesensitive and threonine-sensitive (Azevedo et al., 1997). The lysine-sensitive form of AK, which may also be synergistically feedback inhibited by lysine + S-adenosylmethionine (SAM) (Rognes et al., 1980), is normally predominant in plant tissues accounting for around $50-70 \%$ of the total AK activity (Azevedo et al., 1992a). The threonine-sensitive AK isoenzyme normally accounts for approximately $20 \%$ of the total AK activity, with the clear exception of coix seeds (Lugli et al., 2002).

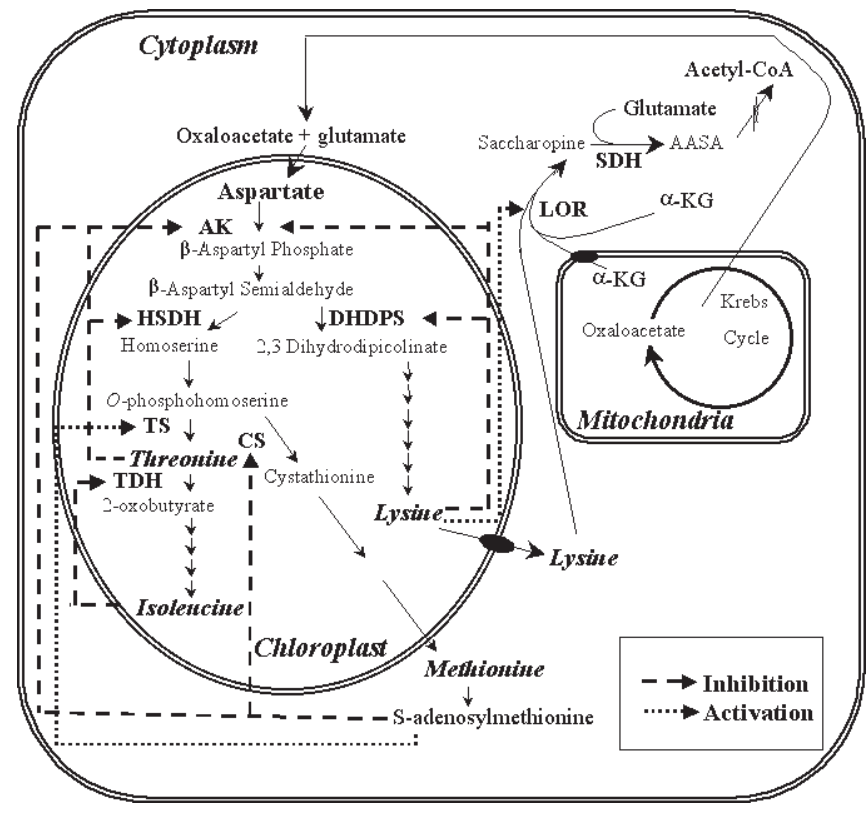

Figure 1. The aspartate metabolic pathway leading to the synthesis of lysine, threonine, methionine and isoleucine.

The conversion of aspartate semialdehyde to homoserine (figure 1) in the presence of the coenzymes NADH or NADPH is catalysed by the enzyme HSDH (Rognes, 1990). Two isoenzymes, one sensitive to threonine feedback inhibition and other resistant to threonine inhibition have been observed in plants (Azevedo et al., 1997). In the case of AK and HSDH, the isoenzymes sensitive to threonine feedback inhibition, have been shown to be part of a single bifunctional polypeptide (Azevedo and Lea, 2001; Paris et al., 2002). Distinct regulatory properties, such as the effects of amino acids, S-2-aminoethyl-L-cysteine (AEC), SAM, calcium and light, among others, have also been investigated for some of the enzymes of the aspartate pathway (Rognes et al., 1980; Azevedo et al., 1992b; Lugli et al., 2000).

In this paper we have described for the first time the isolation of the enzymes involved in threonine biosynthesis, AK and HSDH, from sorghum seeds. Some regulatory aspects have also been investigated and a comparison with other cereal crop enzymes has been presented.

\section{MATERIAL AND METHODS}

Plant material: The massa 03 variety of sorghum (Sorghum bicolor [L.] Moench), kindly donated by Dr. Luiz Gustavo Nussio (Departamento de Produção Animal, Escola Superior de Agricultura “Luiz de Queiroz”, Universidade de São Paulo) was used for the extraction and isolation of the AK and HSDH enzymes. Plants were grown in the experimental station of 
the Departamento de Genética, ESALQ-USP, Piracicaba during the summer season of 2001-2002, and immature sorghum seeds (previous to milky stage [stage 1, 93 days], milky stage [stage 2, 97 days], and after the milky stage [stage 3, 101 days]) were harvested directly into liquid nitrogen and stored at $-70^{\circ} \mathrm{C}$ until used in the extraction procedure.

Since these enzymes had not been previously isolated and characterized from sorghum, several parameters related to extraction, purification and enzyme assays were optimized using stage 2 sorghum seeds as follows:

Extraction of $A K$ and HSDH: Extraction was carried out at $4^{\circ} \mathrm{C}$. Immature sorghum seeds (stage 2) were used and extracted in 5 volumes of 50 mmol.L-1 Tris - $\mathrm{HCl}(\mathrm{pH} 7.4)$ buffer containing $200 \mathrm{mmol} . \mathrm{L}^{-1} \mathrm{KCl}, 0.1 \mathrm{mmol} . \mathrm{L}^{-1} \mathrm{PMSF}$, 0.1 mmol.L-1 EDTA, 1 mmol.L-1 DTT, 2 mmol.L ${ }^{-1}$ L-lysine, 2 mmol.L ${ }^{-1} \mathrm{~L}^{-}$threonine, $10 \%(\mathrm{v} / \mathrm{v})$ glycerol and $5 \%(\mathrm{w} / \mathrm{v})$ PVPP (buffer A). The extract was filtered through six layers of gauze and centrifuged at $10,000 g_{n}$ for $30 \mathrm{~min}$ to remove completely the cell debris from the extract.

Ammonium sulphate precipitation: Ammonium sulphate, the most commonly used salt for fractionating proteins by precipitation was used as a first step of purification and was also used for concentrating AK and HSDH during purification. The crude extract was initially precipitated with three sequences of increasing ammonium sulphate concentration, to determine the optimum concentration:

-Sequence A: $0-20 \% ; 20-40 \% ; 40-60 \%$ and $60-80 \%$ ammonium sulphate saturation;

-Sequence B: 0-30\%;30-50\% and 50-70\% ammonium sulphate saturation;

-Sequence C: 0-30 \%; 30-60 \% and 60-80 \% ammonium sulphate saturation.

Solid ammonium sulphate was added slowly to the extract and stirred for $30 \mathrm{~min}$ at $4^{\circ} \mathrm{C}$. The sample was precipitated at $10,000 g_{\mathrm{n}}$ for $30 \mathrm{~min}$ at $4^{\circ} \mathrm{C}$. The pellet was resuspended with the minimum possible volume of $25 \mathrm{mmol} . \mathrm{L}^{-1} \mathrm{Tris}-\mathrm{HCl}(\mathrm{pH}$ 7.4) buffer containing $1 \mathrm{mmol} . \mathrm{L}^{-1} \mathrm{DTT}, 0.1 \mathrm{mmol} . \mathrm{L}^{-1} \mathrm{~L}-$ lysine, $0.1 \mathrm{mmol} . \mathrm{L}^{-1} \mathrm{~L}-$ threonine and $10 \%(\mathrm{v} / \mathrm{v})$ glycerol (buffer B). The subsequent ammonium sulphate precipitations were carried out under the same conditions using the previous supernatant fraction and each pellet was desalted on Sephadex G-25 columns equilibrated in the same buffer. The desalted samples were used to measure AK and HSDH activities.

AK assay: AK activity was assayed routinely in a final volume of $500 \mu \mathrm{L}$ as described by Brennecke et al. (1996) with modifications according to the results obtained in this investigation. The assay mixture comprised $100 \mu \mathrm{L} 100$ mmol.L-1 Tris - $\mathrm{HCl}(\mathrm{pH}$ 7.4) containing 1 mmol.L-1 DTT and $20 \%(\mathrm{v} / \mathrm{v})$ glycerol, $100 \mu \mathrm{L} 500 \mathrm{mmol}^{-\mathrm{L}^{-1}}$ aspartic acid (pH 7.4), $50 \mu \mathrm{L} 125$ mmol. $\mathrm{L}^{-1}$ magnesium sulphate, $50 \mu \mathrm{L}$ 200 mmol.L-1 ATP (pH 7.4), $50 \mu \mathrm{L} 4$ mol.L-1 hydroxylamine (pH 7.4), $100 \mu \mathrm{L} \mathrm{H}_{2} \mathrm{O}$ and $50 \mu \mathrm{L}$ of enzyme extract. The assay was started by the addition of $50 \mu \mathrm{L}$ ATP and incubated at $35^{\circ} \mathrm{C}$ for $30 \mathrm{~min}$. The assay was terminated by the addition of $500 \mu \mathrm{L}$ of $\mathrm{FeCl}_{3}$ reagent $\left[670 \mathrm{mmol} . \mathrm{L}^{-1} \mathrm{FeCl}_{3}, 370 \mathrm{mmol} . \mathrm{L}^{-1}\right.$ $\mathrm{HCl}$ and $20 \%(\mathrm{w} / \mathrm{v}) \mathrm{TCA}$ ]. After centrifugation for $10 \mathrm{~min}$ at $10000 g_{\mathrm{n}}$, to remove precipitated protein, the absorbance of the supernatant was measured at $505 \mathrm{~nm}$. Controls containing $10 \mu \mathrm{L} 10 \mathrm{mmol} . \mathrm{L}^{-1}$ lysine, $10 \mu \mathrm{L} 10 \mathrm{mmol}^{-\mathrm{L}^{-1}}$ threonine and $10 \mu \mathrm{L} 10 \mathrm{mmol} . \mathrm{L}^{-1}$ lysine plus $10 \mathrm{mmol} . \mathrm{L}^{-1}$ threonine were normally included to ensure that the activity measured was due to AK and to identify the isoenzymes sensitive to lysine and threonine. Three replications (different extracts) were carried out for each assay.

HSDH assay: HSDH activity was assayed spectrophotometrically at $340 \mathrm{~nm}$ in a final volume of $1.0 \mathrm{~mL}$ at $30^{\circ} \mathrm{C}$ as described by Teixeira et al. (1998) with modifications according to the results obtained in this investigation. The assay mixture contained $800 \mu \mathrm{L} 100$ mmol. $\mathrm{L}^{-1}$ Tris- $\mathrm{HCl}$ (pH 9.0) containing $150 \mathrm{mmol} . \mathrm{L}^{-1} \mathrm{KCl}, 1 \mathrm{mmol} . \mathrm{L}^{-1} \mathrm{DTT}$ and 0.5 mmol.L-1 EDTA, $100 \mu \mathrm{L} 200$ mmol.L ${ }^{-1}$ DL-homoserine, 100 $\mu \mathrm{L} 4.8 \mathrm{mmol} . \mathrm{L}^{-1}$ NADP, $50 \mu \mathrm{L}$ of $\mathrm{H}_{2} \mathrm{O}$ and $50 \mu \mathrm{L}$ enzyme. The effect of threonine on HSDH activity was determined by the addition of $10 \mu \mathrm{L}$ of a $10 \mathrm{mmol} . \mathrm{L}^{-1}$ solution of the amino acid to the assay mixture. Three replications (different extracts) were carried out for each assay.

Partial purification of $A K$ and $H S D H$ for determination of the optimum enzyme volume, incubation time, activity during seed development, and tissue specificity: Extraction and purification procedures were carried out at $4^{\circ} \mathrm{C}$. For the optimization of the enzyme assays, immature sorghum seeds (milky stage) were used and extracted in 5 volumes of buffer A. The extract was filtered through six layers of gauze and centrifuged at $10,000 g_{n}$ for 30 min to remove completely the cell debris from the extract. Solid ammonium sulphate was added slowly to $20-60 \%$ saturation by gently stirring for at least $1 \mathrm{~h}$, and the precipitated protein recovered by centrifugation at $10,000 \mathrm{~g}_{\mathrm{n}}$ for $30 \mathrm{~min}$. The protein pellets were dissolved in a small volume of buffer B. The sample was loaded onto a Sephadex G-25 column $(2.5 \times 20 \mathrm{~cm})$ equilibrated with 5 column volumes of buffer $\mathrm{B}$ and run under 
gravity. The desalted sample was used for the determination of optimum enzyme volume, incubation time, activity during seed development, tissue specificity, and NADP and NAD as HSDH substrates.

Optimum enzyme volume for $A K$ and $H S D H$ : The effect of volume of extract on AK and HDSH assays was determined by adding $50,100,150$ and $200 \mu \mathrm{L}$ of partially purified enzyme extract to the assay mixtures as described above.

Optimum time of incubation for AK and HSDH: The effect of time of incubation of the AK and HSDH assays was determined by incubating the assay mixtures for $15,45,75$, 105 and $120 \mathrm{~min}$ at $35^{\circ} \mathrm{C}$.

AK and HSDH activities during seed development: Immature sorghum seeds from the three developing stages were used. The AK and HSDH activities of the partially purified enzyme extract were determined as described above.

Tissue specificity of the AK and HSDH: AK and HSDH were extracted and partially purified as described above, from sorghum leaves, etiolated leaves and roots (normal seedlings and etiolated seedlings) obtained from $15 \mathrm{~d}$ old seedlings grown in a glasshouse at $14 / 10 \mathrm{~h}$ photoperiod (or shade) and $22-25^{\circ} \mathrm{C}$, and immature seeds (stage 2 ) and mature seeds. AK and HSDH activities were determined as described above.

NADP and NAD as co-enzyme substrates for HSDH: HSDH can use either NADP or NAD as the coenzyme substrate. We have tested NADP (4.8 and 2 mmol.L $\left.\mathrm{L}^{-1}\right)$ and NAD (4.8 and 2 mmol. $\left.\mathrm{L}^{-1}\right)$ as substrates for HSDH in the assay mixture, using a partially purified extract (stage 2 ) as the source of enzyme, as described above.

Anion exchange chromatography step-wise elution of AK and $H S D H$ : Partially purified AK and HSDH, following 20-60\% saturated ammonium sulphate precipitation and desalting on a Sephadex G-25 column, were further purified on a DEAESephacel column $\left(2.5 \times 8 \mathrm{~cm}\right.$; flow rate $\left.1 \mathrm{~mL} \cdot \mathrm{min}^{-1}\right)$ equilibrated in buffer B. The column was washed with buffer B and a step-wise elution (0-100, 100-200, 200-300, 300-
400 and 400-500 mmol. $\mathrm{L}^{-1} \mathrm{KCl}$ ) was carried out. A final wash with $1 \mathrm{~mol} . \mathrm{L}^{-1} \mathrm{KCl}$ was also performed and the fractions were analysed for enzyme activities.

Effect of calcium and EGTA on AK and HSDH activities: AK and HSDH activities were determined in the presence of 1.6 mmol.L $\mathrm{L}^{-1} \mathrm{CaCl}_{2}, 1.6$ mmol.L $\mathrm{L}^{-1}$ EGTA and $1.6 \mathrm{mmol} . \mathrm{L}^{-1} \mathrm{CaCl}_{2}$ plus $1.6 \mathrm{mmol}^{-\mathrm{L}^{-1}}$ EGTA. Blanks with and without the compounds being tested were included. Negative controls lacking the substrates, aspartic acid and homoserine, were also assayed on each occasion.

Effect of methionine and valine on AK and HSDH activities: AK and HSDH activities were determined in the presence of 1-5 mmol.L-1 L-methionine and 1-5 mmol.L $\mathrm{L}^{-1} \mathrm{~L}$-valine. Blanks and negative controls were tested as described above.

Effects of lysine, threonine and AEC on AK and HSDH activities: AK and HSDH activities were determined in the presence of 1-5 mmol. $\mathrm{L}^{-1} \mathrm{~L}-$ lysine, 1-5 mmol. $\mathrm{L}^{-1} \mathrm{~L}$-threonine, 1-5 mmol. $\mathrm{L}^{-1} \mathrm{~L}$-lysine plus 1-5 mmol. $\mathrm{L}^{-1} \mathrm{~L}$-threonine and 15 mmol. $\mathrm{L}^{-1}$ AEC. Blanks and negative controls were tested as described above.

Protein determination: The protein concentration of all samples was determined by the method of Bradford (1976) using bovine serum albumin as a standard.

\section{RESULTS AND DISCUSSION}

AK and HSDH tissue specificity: AK and HSDH, which have been previously shown to play an important role in lysine metabolism (Azevedo et al., 1997) in several plant species, have been isolated from sorghum tissues. AK and HSDH activities were initially measured in leaves and roots (light grown and etiolated) obtained from 15 days old seedlings and mature and immature seeds. AK and HSDH activities were shown to be low or zero in all the seedling tissues tested, with the immature seeds exhibiting a much higher activity when compared to leaves and roots (table 1). It has been shown previously for other plant species (e.g. maize and rice) that developing seeds normally exhibit the highest AK and HSDH

Table 1. The specific activity of AK and HSDH isolated from various tissues of sorghum.

\begin{tabular}{|c|c|c|c|c|c|c|}
\hline \multirow{2}{*}{$\begin{array}{c}\text { Specifc activity } \\
\left(\mathrm{nmol} \cdot \mathrm{min}^{-1} \cdot \mathrm{mg}^{-1} \text { prot}\right)\end{array}$} & \multicolumn{6}{|c|}{ Sorghum Tissues } \\
\hline & Leaves & $\begin{array}{l}\text { Etiolated } \\
\text { Leaves }\end{array}$ & $\begin{array}{c}\text { Roots } \\
\text { (Normal Seedlings) }\end{array}$ & $\begin{array}{c}\text { Roots } \\
\text { (Etiolated Seedlings) }\end{array}$ & $\begin{array}{l}\text { Mature } \\
\text { Seeds }\end{array}$ & $\begin{array}{l}\text { Immature } \\
\text { Seeds }\end{array}$ \\
\hline $\mathrm{AK}$ & $2.46 \pm 0.21$ & 0 & $1.83 \pm 0.14$ & 0 & $1.77 \pm 0.22$ & $8.19 \pm 0.43$ \\
\hline HSDH & $0.89 \pm 0.03$ & 0 & $0.31 \pm 0.02$ & 0 & $0.73 \pm 0.05$ & $3.15 \pm 0.22$ \\
\hline
\end{tabular}


activities with very low levels in other tissues (Brennecke et al., 1996; Teixeira et al., 1998; Gaziola et al., 1999), which agree with the results observed in sorghum. Furthermore, it is interesting that no activity was observed in the etiolated tissue which suggest that carbohydrate might induce the synthesis of AK.

AK and HSDH activities in developing seeds: The activities of AK and HSDH enzymes were also determined in the developing sorghum seeds. The three developing stages analyzed exhibited very similar levels of AK and $\mathrm{HSDH}$ activities (table 2), suggesting that any of the three stages could be used for the isolation of the enzymes. However, in other plant species, endosperm or seed developmental stages have shown large variations in the distribution of enzyme activity (Azevedo et al., 1997). In maize, AK activity was shown increase at 12 days after pollination (DAP) reaching a peak of maximum activity at $16 \mathrm{DAP}$, reducing dramatically after this period (Brennecke et al., 1996). In rice, the variation in activity has not been shown to vary as observed in maize, exhibiting higher activity in the milky stage (Teixeira et al., 1998). The determination of enzyme activity during seed development is important for future purification of the enzyme. Furthermore, in the case of AK and HSDH which have been shown to exist as distinct isoenzymes, the analyses of different stages may help to elucidate or determine different regulatory patterns for lysine and threonine biosynthesis during seed development. Studies with maize endosperms have also shown that enzymes involved in the metabolism of lysine exhibit distinct patterns of activity. AK and HSDH, which are involved in lysine and threonine biosynthesis, are normally higher in the early stages of seed development in order to provide lysine for incorporation in the storage proteins. However, the enzymes lysine 2-oxoglutarate reductase (LOR) and saccharopine dehydrogenase, involved in lysine catabolism, exhibit peaks of activity later during the endosperm development, suggesting the degradation of lysine not used in protein synthesis (Gaziola et al., 1999).

Table 2. The specific activity of AK and HSDH isolated from sorghum seeds, at three different stages of development.

\begin{tabular}{cccc}
\hline \multirow{2}{*}{$\begin{array}{c}\text { Specifc activity } \\
(\text { nmol.min }\end{array} \mathrm{mg}^{-1}$ prot $)$} & \multicolumn{3}{c}{ Seed Development Stage } \\
\cline { 2 - 4 } & Stage 1 & Stage 2 & Stage 3 \\
\hline AK & $7.12 \pm 0.63$ & $6.89 \pm 0.59$ & $6.87 \pm 0.53$ \\
HSDH & $3.27 \pm 0.21$ & $3.33 \pm 0.33$ & $3.41 \pm 0.18$ \\
\hline
\end{tabular}

Based on these results and the data from the literature, seeds at stage 2 were used for the partial purification of the enzymes, the optimization of the enzyme assays and the other analyses carried out in this study.

Ammonium sulphate precipitation: Precipitation by the addition of neutral salts is probably the most commonly used simple method for fractionating proteins. The precipitated protein is usually not denatured and activity is recovered upon re-dissolving the pellet. In addition, these salts can stabilise proteins against denaturation, proteolysis or bacterial contamination (Englard and Seifter, 1990). Solid ammonium sulphate is the most commonly used salt and was used as the first step of purification and also used for concentrating AK and HSDH during this process.

AK has been shown to precipitate between $30-55 \%$ saturation of ammonium sulphate in Cicer (Dey and GuhaMukherjee, 2000), 20-50\% in rice (Lugli et al., 2000), 0-60\% in Nicotiana sylvestris leaves (Frankard et al., 1992), 35-60\% in maize anthers, immature endosperms and scutellum (Brennecke et al., 1996; Gaziola et al., 1999), 40-60\% in carrot cells (Relton et al., 1988) and 0-66\% in tobacco (Shaul and Galili, 1993). Three sequences of precipitation with ammonium sulphate were tested using stage 2 sorghum seeds (figure 2). AK activity could be almost completely recovered from the pellets precipitated with $20-60 \%$ saturation of solid ammonium sulphate with very little left over after $60 \%$ (figures 2A, 2C and 2E). The HSDH activity also could be recovered with $20-60 \%$ with ammonium sulphate saturation (figures 2B, 2D and 2F). Although both enzymes could be recovered in the same fractions, it appears that HSDH activity is more concentrated between $30-50 \%$ saturation, whereas AK has a much wider distribution which could be due to different isoenzyme distribution. These results were not significantly different from the results previously reported for other plant species and the $20-60 \%$ ammonium sulphate saturation was adopted during enzyme purification, allowing the purification of both enzymes simultaneously.

Enzyme assays optimization: A fundamental aspect in determining enzyme activity and further characterization of the enzyme is that the assay is reliable and enzyme activity is determined accurately. Previous reports have used distinct assay conditions depending on the plant or even tissue to be analyzed. Since these enzymes had not been previously isolated from sorghum, we decided to check some of these conditions for AK and HSDH assays in order to ensure accurate determinations of enzyme activity. 

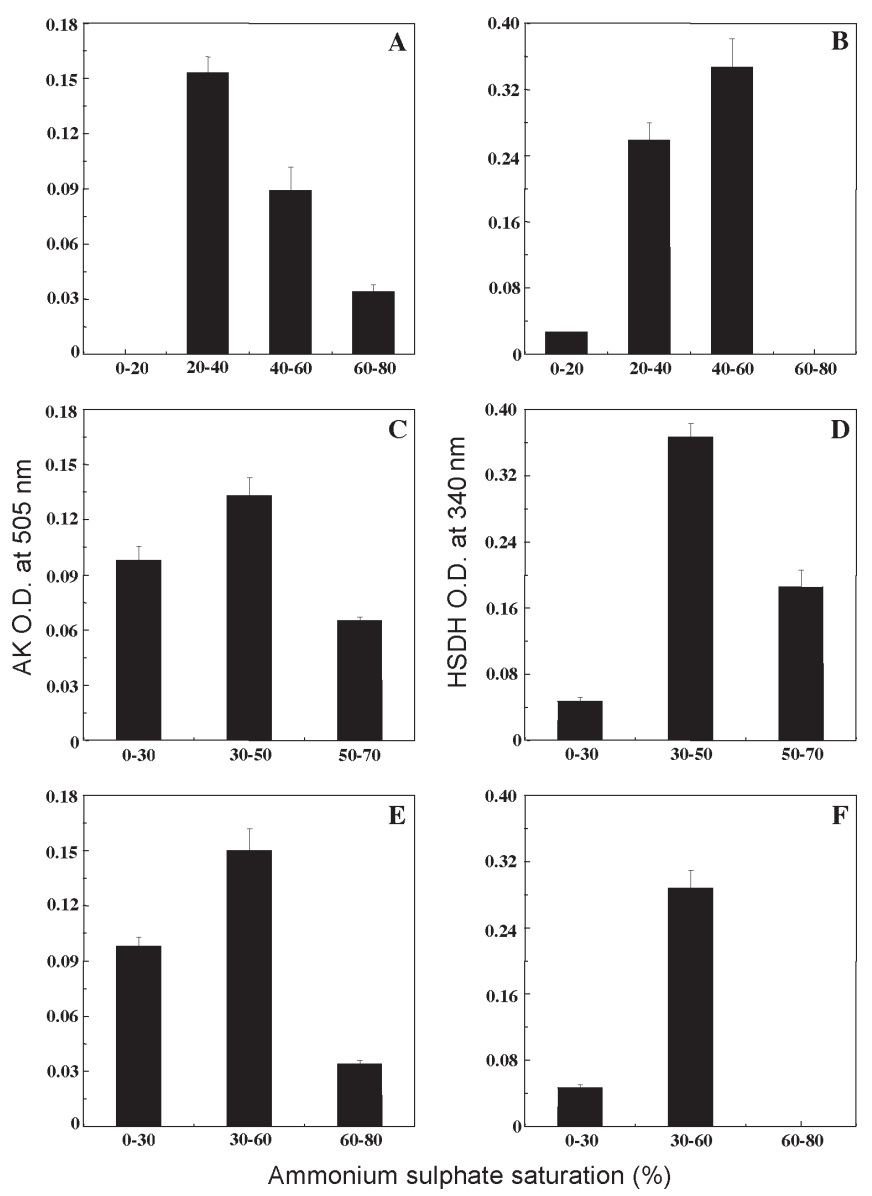

Figure 2. Ammonium sulphate precipitation of $A K(A, C, E)$ and $\operatorname{HSDH}(\mathrm{B}, \mathrm{D}, \mathrm{F})$ isolated from sorghum seeds.

In many situations, sample volume can be reduced due to the amount of tissue or protein enzyme in the extract and very little can be used for the enzyme assay during a purification procedure. For instance, in the case of AK, which exhibits very low activity levels, larger amount of enzyme must be added to the assay mixture. Furthermore, the presence of isoenzymes that can be identified based on inhibition patterns require the use of more sample in assay test. We have established a total of $1 \mathrm{~mL}$ volume for the enzyme assays in this research. Previous reports have routinely used $100 \mu \mathrm{L}$ of plant extract as a standard volume for the assays (Bonner and Lea, 1990; Azevedo et al., 1992c). In this study, we measured both enzyme activities varying the amount of plant extract added to the assays (figure 3). The increase in plant extract added to the AK assay did not ensure a linear increase of AK activity above $100 \mu \mathrm{L}$ (figure $3 \mathrm{~A}$ ), although a continuous increase in activity was observed up to $200 \mu \mathrm{L}$ enzyme extract. For HSDH, plant extract volumes higher than $100 \mu \mathrm{L}$ did not alter HSDH activity, suggesting that volumes higher than 100 $\mu \mathrm{L}$ should be avoided (figure $3 \mathrm{~B}$ ). Moreover, when plant extracts containing a higher concentration of enzyme protein is used, dilutions or lower volumes of extract should be used to ensure that over or under estimated HSDH activities are not determined.

Another aspect that should be considered is how long the assay is run. As observed for enzyme volume used in the assay, it is important that the assay also shows linearity over the period of incubation. Similarly to the results observed for enzyme volume, the AK assay did not show a linear increase in activity if time zero is considered, since a higher increase in activity was observed during the first 15 min of incubation,
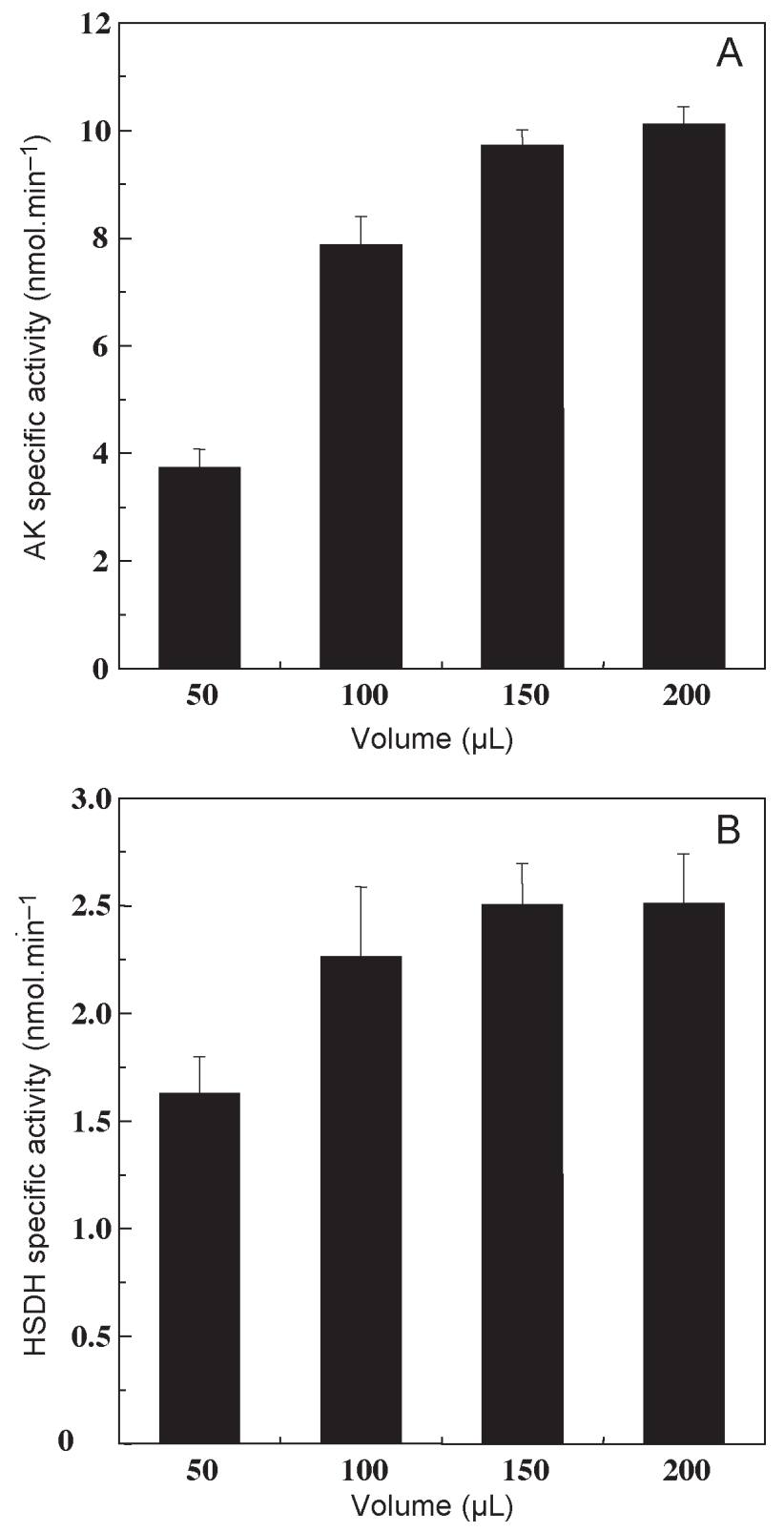

Figure 3. The effect of the volume of sorghum seed extract in the assay, on the determined activities of AK (A) and HSDH (B). 
but this increase was linear afterwards for up to $105 \mathrm{~min}$ of incubation (figure 4A). A very similar variation was observed for HSDH (figure 4B). Although a more detailed analysis of each assay can be carried out to check other parameters (e.g. substrate concentration), the combination of period of incubation and volume of plant extract should be considered during the purification procedure and altered according to the variations in the concentration of AK and HSDH enzyme proteins in the extracts. Based on these data, we have used in all further analyses $50 \mu \mathrm{L}$ of plant extract, but reduced the time of incubation in both assays to periods varying between 10-30 min, depending on the enzyme to be measured and concentration of enzyme protein in the extracts.
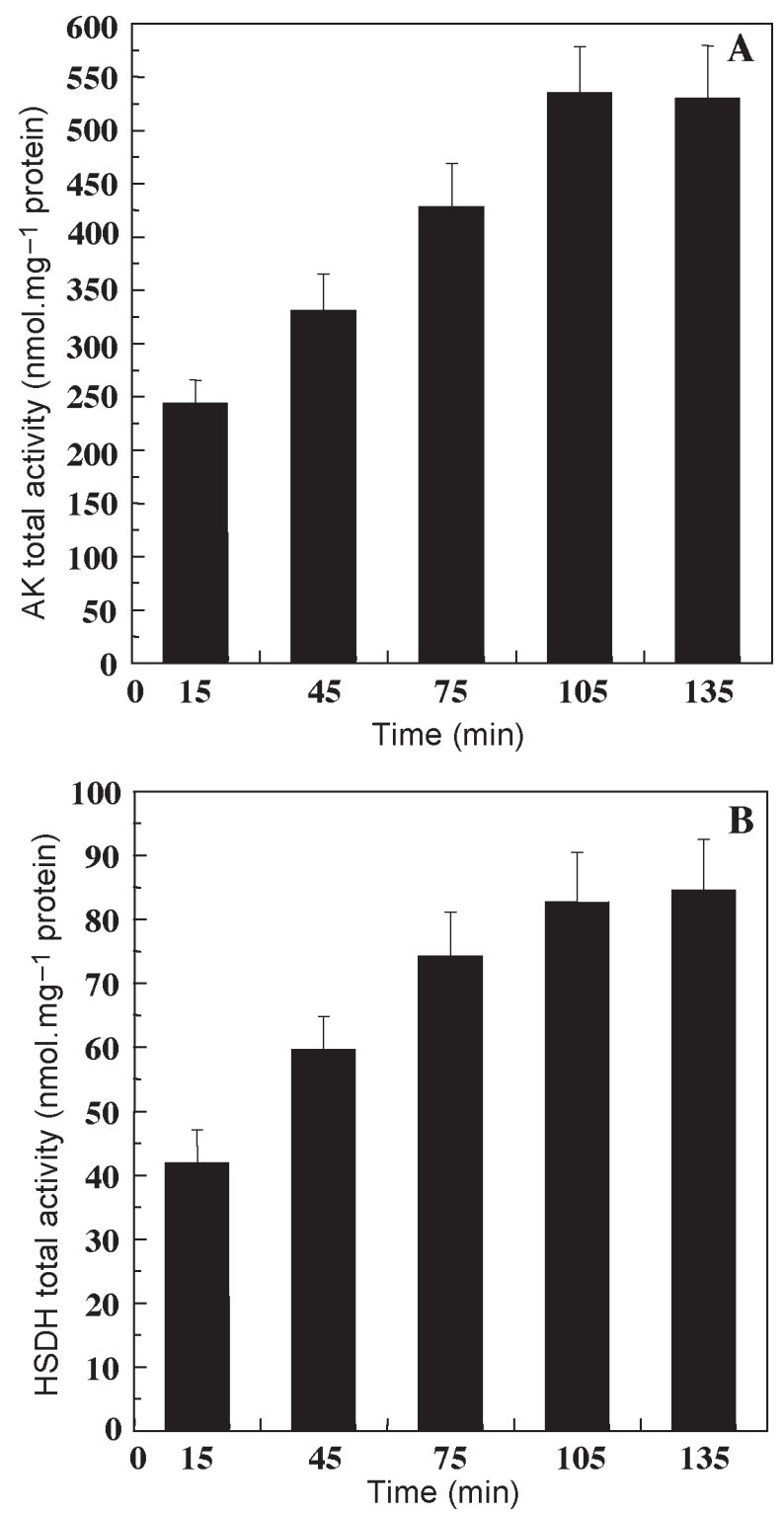

Figure 4. The effect of assay time on the determined activities of AK (A) and HSDH (B) isolated from sorghum seeds.
$N A D P$ and $N A D$ as substrates for HSDH: In higher plants, HSDH catalyses the reduction of aspartate semialdehyde to homoserine (figure 1) by NADPH, with NADH also serving as a co-enzyme substrate (Azevedo and Lea, 2001). The great majority of the investigations carried out with HSDH have measured the activity in the reverse direction of the reaction, using $\mathrm{NAD}^{+}$or $\mathrm{NADP}^{+}$as co-enzyme substrates, due to the fact that aspartate semialdehyde is a difficult substrate to obtain. The sorghum HSDH was shown to use $\mathrm{NADP}^{+}$more efficiently, even at the lower concentration tested, when compared to the HSDH activity obtained when using $\mathrm{NAD}^{+}$ (table 3). Although variation in the range of efficiency between $\mathrm{NADP}^{+}$and $\mathrm{NAD}^{+}$has been observed in the literature among plant species, $\mathrm{NADP}^{+}$was consistently more efficient as observed in sorghum.

Enzymes partial purification: In order to study some properties of AK and HSDH, the enzymes were partially purified from developing stage 2 sorghum seeds using ammonium sulphate precipitation, followed by step-wise elution from an anion-exchange chromatography column. Both enzymes were co-eluted between 100 and 300 mmol.L-1 $\mathrm{KCl}$ (figure 5). Residual $\mathrm{AK}$ activity from the second peak (200-300 mmol.L-1 $\mathrm{KCl}$ ), was also observed in the 300-400 mmol. $\mathrm{L}^{-1} \mathrm{KCl}$ step-wise fraction (figure 5A). Preliminary analysis of the fractions containing higher AK and $\mathrm{HSDH}$ activities in the presence of lysine and threonine, did not allow the identification of specific peaks containing the distinct isoenzymes of AK (lysine-sensitive and threonine-sensitive) or HSDH (threonine-resistant and threonine-sensitive) (data not shown). Therefore, the fractions containing AK activity and HSDH activity were combined and used in all further analyses.

Effect of lysine, threonine and AEC on AK and HSDH activities: The combined fractions containing AK and HSDH activities from the step-wise anion-exchange chromatography procedure were analyzed in the presence of the amino acids lysine and threonine (figure 6). Both amino acids were shown to be able to inhibit AK, indicating the existence of at least two isoenzymes of $\mathrm{AK}$, one sensitive to lysine and the other sensitive to threonine, even though the purification procedure used was not able to separate distinct peaks (figure 6A). The inhibition patterns also revealed that the lysine-sensitive AK isoenzyme is predominant in sorghum seeds since lysine inhibited AK activity more strongly, when compared to threonine, at all concentrations tested (figure 6A). Moreover, when both amino acids were added together to the assay 
Table 3. The activity of HSDH isolated from sorghum seeds using either $\mathrm{NAD}^{+}$or $\mathrm{NADP}^{+}$as a substrate.

\begin{tabular}{|c|c|c|c|c|}
\hline \multirow{2}{*}{$\begin{array}{c}\text { Specifc activity } \\
\left(\text { nmol.min }{ }^{-1} \cdot \mathrm{mg}^{-1} \text { prot }\right)\end{array}$} & \multicolumn{4}{|c|}{ Substrate- } \\
\hline & $\mathrm{NADP}^{+}$ & $\mathrm{NADP}^{+}$ & $\mathrm{NAD}^{+}$ & $\mathrm{NAD}^{+}$ \\
\hline & $\left(2.0\right.$ mmol. $\left.\mathrm{L}^{-1}\right)$ & $\left(4.8 \mathrm{mmol}^{-\mathrm{L}^{-1}}\right)$ & $\left(2.0\right.$ mmol. $\left.\mathrm{L}^{-1}\right)$ & $\left(4.8 \mathrm{mmol} . \mathrm{L}^{-1}\right)$ \\
\hline HSDH & $0.905 \pm 0.057$ & $1.302 \pm 0.028$ & $0.199 \pm 0.055$ & $0.529 \pm 0.048$ \\
\hline
\end{tabular}

mixture, a stronger inhibitory effect was observed further confirming the existence of two isoenzymes of AK in sorghum (figure 6A). According to previous reports, lysine has been widely shown to be the main inhibitor of AK activity in higher plants (Azevedo et al., 1997), the only clear exception being coix seeds, in which the threonine-sensitive AK isoenzyme is predominant (Lugli et al., 2002). AK from sorghum appears to follow the pattern of isoenzyme distribution exhibited by the majority of other plant species. The addition of AEC to the assay mixture is also interesting, since this lysine analogue was not able to produce a strong inhibition of AK activity (figure 6A). AEC has been show to be able to substitute for lysine in proteins (Azevedo et al., 1997) and also to act as a substrate for LOR activity, but not to the same extent as lysine (Gaziola et al., 2000) in rice seeds. The effects of these amino acids on HSDH activity were very different (figure 6B), with only a slight inhibition by lysine at the highest concentration tested, which has not been reported previously. Threonine inhibited HSDH activity more effectively above the concentration of $2 \mathrm{mmol} . \mathrm{L}^{-1}$, but still the majority of HSDH activity could not be inhibited by the amino acid, indicating that at least two isoenzymes of HSDH are present in sorghum seeds, one resistant to threonine inhibition which is

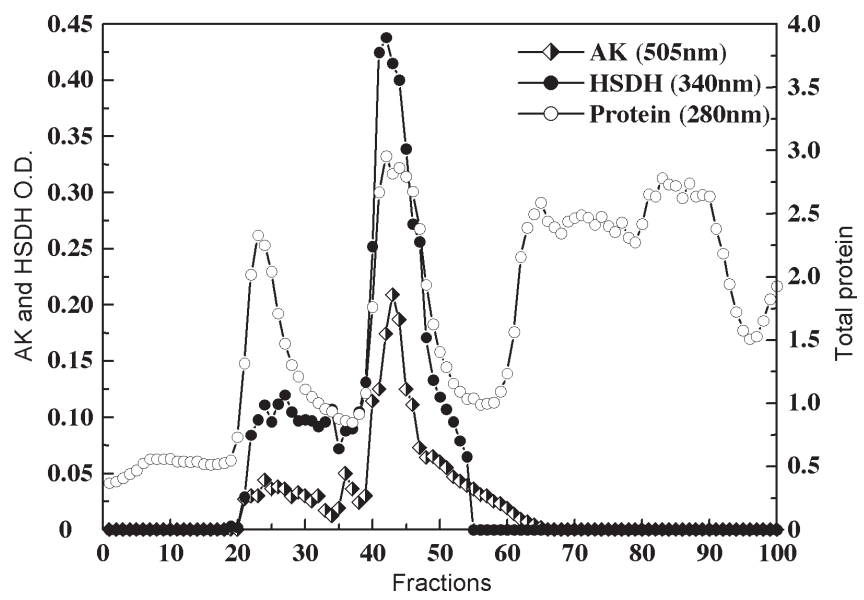

Figure 5. Step-wise elution of AK and HSDH isolated from sorghum seeds, from an anion-exchange chromatography column, using increased concentrations of $\mathrm{KCl}$. predominant, and the other sensitive to threonine inhibition, a pattern that essentially agrees with what has been reported for HSDH from other plant species (Azevedo et al., 1997). Surprisingly, the addition of lysine and threonine together produced a stronger inhibition of HSDH when compared to threonine alone, which has not been reported previously. In a similar way, AEC also inhibited HSDH activity, but at the lower concentration tested. Further investigation with separated HSDH and AK isoenzymes may help to elucidate such results.

Effect of methionine and valine on AK and HSDH activities: The effects of methionine and valine on AK and HSDH activities have been investigated previously in other plant species and have shown distinct results (Lugli et al., 2000). In sorghum seeds, the addition of both amino acids to the assay mixture did not result in any significant alteration in AK activity (figure 6C). However, at 5 mmol. $\mathrm{L}^{-1}$ methionine partially inhibited HSDH activity, whereas valine was able to inhibit HSDH activity to the same extent as methionine at all concentrations tested (figure 6D). Methionine is also synthesized in the aspartate metabolic pathway (figure 1), whereas valine is not. The inhibition of HSDH activity by methionine and valine had not been previously tested or reported, as far as we are aware. These results are difficult to explain and further investigation is clearly necessary.

Effect of calcium and EGTA on AK and HSDH activities: It is well established that calcium plays an important role in plant signaling (Hetherington and Bownlee, 2004). The regulatory action of calcium ranges from control of ion transport to gene expression. A rapid and transient increase in cytosolic calcium concentration upon different extra-cellular stimuli is considered as the primary event in different physiological responses (Shacklock et al., 1992) and in the activation of different biochemical pathways (Karchi et al., 1995). In earlier studies, it was shown that phytochrome activation of AK is mediated through calcium (Dey and Guha-Mukherjee, 1999). Further evidence was provided when elevated levels of 
intracellular calcium in immature seeds activated AK (Dey and Guha-Mukherjee, 2000). However, such a regulatory role for calcium on AK could not be confirmed in a series of other reports with different plants species (Azevedo and Lea, 2001). AK isoenzymes highly purified from carrot cell cultures (Relton et al., 1988), maize cell cultures (Azevedo et al., 1992c) and rice seeds (Lugli et al., 2000) were not affected by calcium and EGTA. The effect of calcium and EGTA on the combined pool of fractions containing AK and HSDH activity from the step-wise anion exchange chromatography was tested (figure 6). The activity of AK was not affected by any of the treatments, indicating that calcium does not regulate AK activity from sorghum seeds (figure 6E). Although calcium did not stimulate HSDH activity, the addition of EGTA alone and in combination with extra calcium suggest
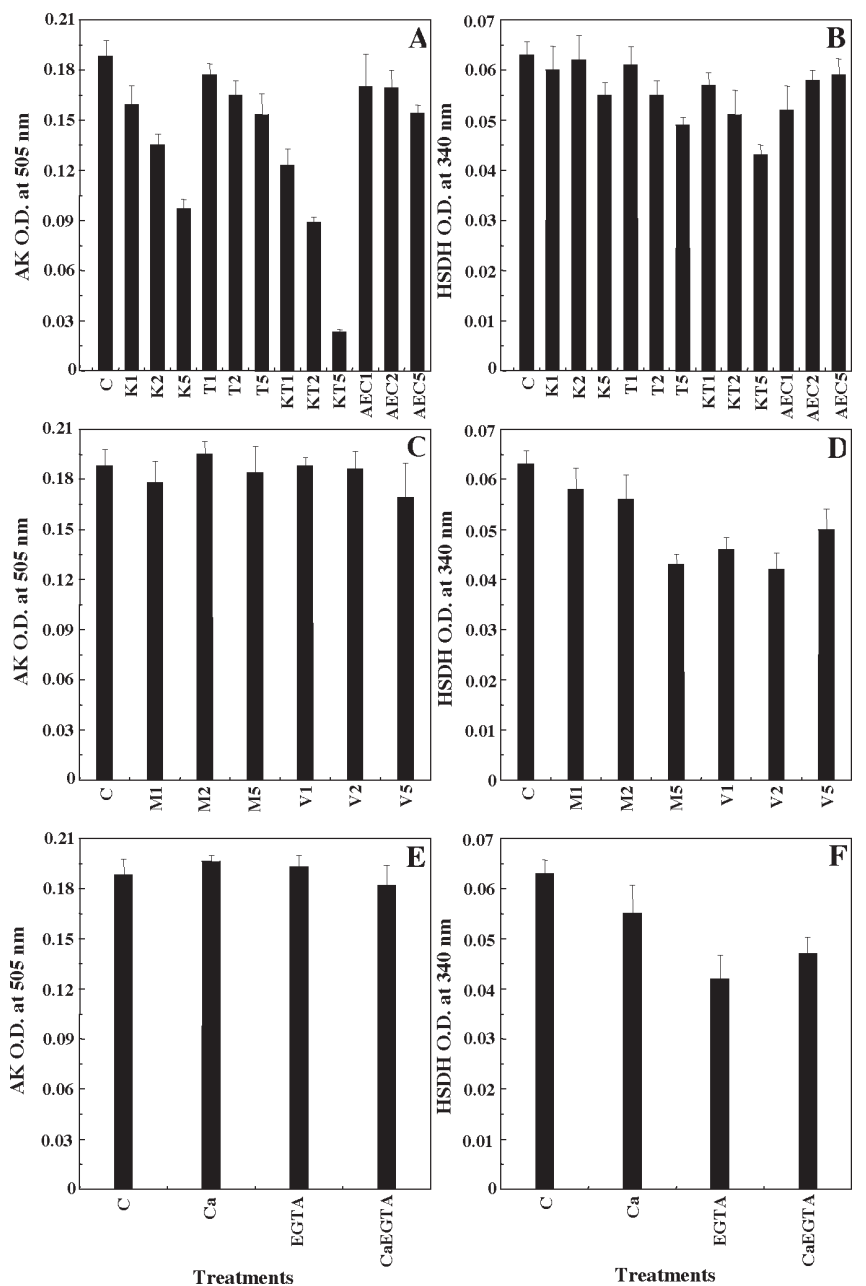

Figure 6. The effect of the addition of amino acids (K, lysine; $\mathrm{T}$, threonine; $\mathrm{M}$, methionine; $\mathrm{V}$, valine), $\mathrm{Ca}$, EGTA and aminoethyl L-cysteine (AEC) alone and in combination at $\mathrm{mM}$ concentrations, on the determined activities of AK $(\mathrm{A}, \mathrm{C}, \mathrm{E})$ and $\mathrm{HSDH}(\mathrm{B}, \mathrm{D}, \mathrm{F})$ isolated from sorghum seeds. that HSDH may be stimulated by calcium under some circumstances (figure 6F). It is likely that the calcium concentration within the cell system is high enough to maintain HSDH activity at its maximum, so that the addition of extra calcium does not further stimulate the activity, but addition of EGTA could reduce HSDH activity (figure 6F). Although a controversy exists about the regulatory role for calcium on AK activity in plants, such a regulation by calcium of enzymes involved in lysine catabolism has been reported (Kemper et al., 1998; Gaziola et al., 2000).

A comprehensive purification procedure is under way on our laboratory which will allow the isolation of the specific isoenzymes from sorghum and will help to characterize the properties of each isoenzyme. Furthermore, we will also be able to identify the existence of a bifunctional enzyme containing threonine-sensitive AK and HSDH domains as has been reported in other plant species (Azevedo, 2002).

Acknowledgements: This work was funded by Fundação de Amparo à Pesquisa do Estado de São Paulo (FAPESP - Grant $\left.n^{\circ} .01 / 13216-4\right)$ and The British Council. R.A.A. and R.R.F. also would like to thank CNPq and FAPESP (00/05960-2), respectively, for the fellowship and scholarship granted.

\section{REFERENCES}

Azevedo RA, Blackwell RD, Smith RJ, Lea PJ (1992a) Three aspartate kinase isoenzymes from maize. Phytochemistry 31:3725-3730.

Azevedo RA, Smith RJ, Lea PJ (1992b) Aspartate kinase regulation in maize: regulation by calcium and calmodulin. Phytochemistry 31:3735-3737.

Azevedo RA, Smith RJ, Lea PJ (1992c) Aspartate kinase regulation in maize: evidence for co-purification of threonine-sensitive aspartate kinase and homoserine dehydrogenase. Phytochemistry 31:3731-3734.

Azevedo RA, Arruda P, Turner WL, Lea PJ (1997) The biosynthesis and metabolism of the aspartate derived amino acids in higher plants. Phytochemistry 46:395-419.

Azevedo RA, Lea PJ (2001) Lysine metabolism in higher plants. Amino Acids 20:261-279.

Azevedo RA (2002) Analysis of the aspartic acid metabolic pathway using mutant genes. Amino Acids 22:217-230.

Azevedo RA, Damerval C, Landry J, Lea PJ, Bellato CM, Meinhardt LW, Le Guilloux M, Delhaye S, Toro AA, Gaziola SA, Berdejo BDA (2003) Regulation of maize lysine metabolism and endosperm protein synthesis by opaque and floury mutations. Eur. J. Biochem. 270:4898-4908.

Azevedo RA, Damerval C, Lea PJ, Landry J, Bellato CM, Meinhardt LW, Le Guilloux M, Delhaye S, Toro AA, Gaziola SA, Varisi VA, Gratão PL (2004) Genetic control of lysine metabolism in maize endosperm mutants. Funct. Plant Biol. 31:339-348. 
Bonner PLR, Lea PJ (1990) Enzymes of lysine synthesis. In: Dey PM, Harborne JB, Lea PJ (eds), Methods in Plant Biochemistry, Enzymes of Primary Metabolism, vol 3, pp.297-315. Academic Press, San Diego, USA.

Bradford MM (1976) A rapid and sensitive method for the quantitation of microgram quantities of protein utilizing the principle of protein-dye binding. Anal. Biochem. 72:248-259.

Brennecke K, Souza Neto AJ, Lugli J, Lea PJ, Azevedo RA (1996) Aspartate kinase in the maize mutants Ask1-LT19 and Opaque-2. Phytochemistry 41:707-712.

Dey M, Guha-Mukherjee S (1999) Phytochrome activation of aspartate kinase in etiolated chickpea (Cicer arietinum) seedlings. J. Plant Physiol. 154:454-458.

Dey M, Guha-Mukherjee S (2000) Aspartate metabolism in Cicer immature seeds requires $\mathrm{Ca}^{2+}$, protein phosphorylation and dephosphorylation. Plant Sci. 150:85-91.

Englard S, Seifter S (1990) Precipitation techniques. In: Deutscher MP (ed), Guide to Protein Purification, Methods in Enzymology, vol 182, pp.285-301. Academic Press, San Diego, USA.

Fornazier RF, Azevedo RA, Ferreira RR, Varisi VA (2003) Lysine catabolism: flow, metabolic role and regulation. Braz. J. Plant Physiol. 15:9-18.

Frankard V, Ghislain M, Jacobs M (1992) Two feedbackinsensitive enzymes of the aspartate pathway in Nicotiana sylvestris. Plant Physiol. 99:1285-1293.

Galili G, Galili S, Lewinsohn E, Tadmor Y (2002) Genetic, molecular, and genomic approaches to improve the value of plant foods and feeds. Crit. Rev. Plant Sci. 21:167-204.

Gaziola SA, Alessi ES, Guimarães PEO, Damerval C, Azevedo RA (1999) Quality protein maize: a biochemical study of enzymes involved in lysine metabolism. J. Agric. Food Chem. 47:1268-1275.

Gaziola SA, Sodek L, Arruda P, Lea PJ, Azevedo RA (2000) Degradation of lysine in rice seeds: effect of calcium, ionic strength, S-adenosylmethionine and S-2-aminoethyl-Lcysteine on the lysine 2-oxoglutarate reductasesaccharopine dehydrogenase bifunctional enzyme. Physiol. Plant. 110:164-171.

Hetherington AM, Brownlee C (2004) The generation of $\mathrm{Ca}^{2+}$ signals in plants. Ann. Rev. Plant Biol. 55:401-427.

Karchi H, Miron D, Ben-Yaacov S, Galili G (1995) The lysinedependent stimulation of lysine catabolism in tobacco seed requires $\mathrm{Ca}^{2+}$ and protein phosphorylation. Plant Cell 7:1963-1970.

Kemper EL, Cord-Neto G, Capella AN, Gonçalves-Butruille M, Azevedo RA, Arruda P (1998) Structure and regulation of the bifunctional enzyme lysine-ketoglutarate reductase- saccharopine dehydrogenase in maize. Eur. J. Biochem. 253:720-729.

Kingston-Smith AH, Thomas HM (2003) Strategies of plant breeding for improved rumen function. Ann. Appl. Biol. 142:13-24.

Leng RA (1990) Factors affecting the utilization of poor quality forages by ruminants particularly under tropical conditions. Nutr. Res. Rev. 3:277-303.

Lugli J, Campbell A, Gaziola SA, Smith RJ, Lea PJ, Azevedo RA (2002) Enzymes of lysine metabolism from Coix lacrima-jobi seeds. Plant Physiol. Biochem. 40:25-32.

Lugli J, Gaziola SA, Azevedo, RA (2000) Effects of calcium, S-adenosylmethionine, S-(2-aminoethyl)-L-cysteine, methionine, valine and salt concentration on rice aspartate kinase isoenzymes. Plant Sci. 150:51-58.

Paris S, Wessel PM, Dumas R (2002) Overproduction, purification, and characterization of recombinant bifunctional threonine-sensitive aspartate kinasehomoserine dehydrogenase from Arabidopsis thaliana. Protein Express. Purif. 24:105-110.

Relton JM, Bonner PLR, Wallsgrove RM, Lea PJ (1988) Physical and kinetic properties of lysine-sensitive aspartate kinase purified from carrot cell suspension culture. Biochim. Biophys. Acta 953:48-60.

Rognes SE (1990) Threonine biosynthesis. In: Dey PM, Harborne JB, Lea PJ (eds), Methods in Plant Biochemistry, Enzymes of Primary Metabolism, vol 3, pp.315-325. Academic Press, San Diego, USA.

Rognes SE, Lea PJ, Miflin BJ (1980) S-adenosylmethionine - a novel regulation of aspartate kinase. Nature 287:357-359.

Shacklock PS, Read ND, Trewavas AJ (1992) Cytosolic free calcium mediates red light-induced photomorpho-genesis. Nature 358:753-755.

Shaul O, Galili G (1993) Concerted regulation of lysine and threonine synthesis in tobacco plants expressing bacterial feedback-insensitive aspartate kinase and dihydrodipicolinate synthase. Plant Mol. Biol. 23:759-768.

Teixeira CMG, Gaziola AS, Lugli J, Azevedo RA (1998) Isolation, partial purification and charaterization of aspartate kinase isoenzymes from rice seeds. J. Plant Physiol. 153:281-289.

Vauterin M, Frankard V, Jacobs M (1999) The Arabidopsis thaliana dhdps gene encoding dihydrodipicolinate synthase, key enzyme of lysine biosynthesis, is expressed in a cell-specific manner. Plant Mol. Biol. 39:695-708.

Vernaillen S, Laureys F, Jacobs M (1993) A potential screening system for identifying Sorghum ecotypes with increased lysine in the seeds. Plant Breed. 111:295-305. 